\title{
MANIFESTATION OF SATANISM IN RUSSIA
}

\author{
Roman R. Davletshin ${ }^{1}$ \\ Vladimir N. Rogatin ${ }^{2}$
}

\begin{abstract}
The article discusses the representation of satanic thematic communities on VKontakte and analyzes their numbers. The lack of sociological data on the number of followers of Satanic movements determines the study of the field ideas are broadcast in. The study identified groups that cover the audience of more than 54,000 people, of which more than 23,000 indicated their

faces in modern Russia. The popularity of satanic ideas is enhanced, among other things, by media content where Satan is considered from an alternative point of view and thus the romanticization of his image can be formed. Critical media content about the activities of satanic groups can also form the attractiveness of such groups in the teenage milieu as a form of protest.
\end{abstract} residence in the Russian Federation. The consolidation of supporters of satanic ideas in the virtual space implies their further manifestation in real life. The destructive manifestation of the activity of satanic groups or persons who consider themselves to be Satanism is represented by judicial acts, which were distributed according to the classification of V.A. Martinovich into two groups youth and rationalistic Satanism. The presented judicial acts are dominated by youth Satanism, which clearly shows the challenges society

Keywords: satanism, NSD, sect, social networks, destructive trends.

\section{Introduction}

One of the controversial phenomena in the religious life of the Russian Federation is Satanism, which is represented by religious groups and thematic communities. Having deep occult roots, Satanism as an independent structured religious movement was established only at the end of the XIX century in the USA (Nosachev, 2017)

\footnotetext{
${ }^{1}$ Kazan Federal University. e-mail: Blaide@ rambler.ru. Tel.: +79655835534 .

${ }^{2}$ Kazan Federal University. e-mail: Blaide@ rambler.ru. Tel.: +79655835534 .
} 
and penetrated the territory of Russia, where it is perceived and regarded as a radical ideology of aggression and violence. The peak of Satanism in Russia occurred in the 90s of the XX century. In these years, domestic media regularly discussed incidents related to teenage animal abuse. Satanic symbols and attributes in this period were used by numerous subcultural and countercultural communities.

\section{Modern Russian historiography} has no single universally accepted classification of Satanism in the scientific community. So, one can meet the division of Satanists into "orthodox devil worshipers", "Luciferian" and "reformed devil worshipers (followers of LaVey)" or division into "separate few adherent family groups", "satanic groups", “demon worship groups", "separately practicing sorcerers and witches", "some currents of shamanism", "some secret societies" and "occult groups". The Satanists themselves also derive different classifications of Satanism; some divide it into "atheistic" and "theistic" (with many variations), others distinguish between "true Satanists" (moderate individualists) and "calling themselves
Satanists" (devil worshipers, "metalworkers", laveists and others). In our opinion, it is advisable to use the classification of Satanism proposed by V.A. Martinovich, which distinguishes two types of Satanism: "youth" and "rationalistic" Satanism. Youth Satanism "is practiced by people aged from 13 to 25 years and is understood as a symbol of rebellion against any government. It is youth Satanism that is responsible for setting fire to churches, desecrating cemeteries, and killing animals and people" (Martinovich, 2018). In the second, "The God of rational Satanism is the Satanist himself, who does not recognize any other authorities except itself" (Martinovich, 2018).

\section{$2 \quad$ Methods}

The empirical basis of the study is the results of the analysis and generalization of the materials of the satanic communities on VKontakte and criminal cases in the public domain. The systematization of judicial acts in which the Satanists appeared was presented according to the classification of V.A. Martinovich. As part of the study, the Internet is considered as a global social and communication network. Social 
networks have anthropocentric characteristics despite their technogenic origin.

\section{$3 \quad$ Results and discussion}

The problem of studying Satanism in the Russian Federation is the fact that, due to the lack of sociological research, the approximate or indicative figures of the followers of this trend are unavailable to us. The society's rejection of the existence of religious organizations openly declaring their satanic orientation and engaged in active "missionary" activities led to the shift of attention of satanic activists to social networks. The most popular social networks in the Russian Federation are Odnoklassniki and VKontakte. The first is focused on users over 30 years old, the second - youth under 25 years old. VKontakte was launched in October 2006 and was introduced as a social network for students and graduates of Russian universities. The VKontakte interface is completely Russianlanguage, and the network itself is adapted for the exchange of visual information - text, video or photo.

As part of a study conducted in February 2019, we tracked the number and dynamics of subscribers of ten satanic communities on VKontakte.

1. The AVE SATAN community - total 54,553 users. Users who indicate their residence in the Russian Federation - 23,754.

2. The Satanism community total 34,857 users. Users who indicate their residence in the Russian Federation $-15,285$.

3. The Satanist community total 28,045 users. Users who indicate their residence in the Russian Federation - 10,076.

4. The Lucifer Rising community - total 25,515 users. Users who indicate their residence in the Russian Federation - 10,976.

5. The Bible of Satan community - total 13,404 users. Users who indicate their residence in the Russian Federation - 5448.

6. The Devil - Satan community - total 12,189 users. Users who indicate their residence in the Russian Federation - 4924.

7. The ORDER OF SATAN community - total 7049 users. Users who indicate their residence in the Russian Federation - 2858. 
8. The $\dagger_{-}+\_+$Cult of Lucifer †_†_ + community - total 5587 users. Users who indicate their residence in the Russian Federation - 2317.

9. The Satanic Church of the Russian Federation community - total 4044 users. Users who indicate their residence in the Russian Federation 1847.

10. The Lucifer-LuciferianismSatan-Satanism community - total 2805 people. Users who indicate their residence in the Russian Federation 1201.

Most of these show to have a steady increase in the number of subscribers. On average, the total number of participants in satanic communities who indicated Ukraine, Belarus or Kazakhstan as their place of residence, in relation to the indicated RF, is about $30 \%$. At the same time, not less than a third of the participants in the considered communities indicate the place of residence of the 5 most populated cities of the Russian Federation, the official total population of which does not exceed $16 \%$ of the total number of citizens of the Russian Federation, which indicates a high degree of urbanization of modern
Satanism. Anyway, it should be understood that a person who has joined a community of a satanic orientation does not necessarily share a satanic worldview. However, given the voluntary nature of subscription, it is necessary to note the growing interest of the population in the satanic communities. A comparison of the results of a content analysis study of two satanic communities allows us to draw a number of conclusions. In addition to the obvious difference in the design of community materials (in form) and the number of subscribers, the communities differ from each other in the content that is paramount for the functioning and classification of religious communities, such as the presence of esoteric and occult materials, as well as the presence of prayers and descriptions of cult practices. In the existing series of differences, we single out the most striking ones: literature published by communities and the number of reposts from other groups (as an indicator of intergroup coordination of the satanic community). It should also be noted materials in communities devoted to criticism of representatives of other faiths and religiosity as such. The 
presented groups clearly show that in terms of the number of users, thematic satanic communities prevail over communities representing specific satanic religious groups or organizations.

The decisions of the courts of the Russian Federation show a slightly different trend. According to Article 28 of the Constitution of the Russian Federation and Article 3 of the Federal Law "On Freedom of Conscience and on Religious Associations," believers (of authorized denominations) are free to hold meetings without any organization at all, exercising their right approved in, and also to create and unite to religious groups that do not require mandatory state registration. Note that the cult practice of even registered religious organizations can consciously or unconsciously contain rituals, rituals, prayers and other components of Satanism, especially given the high variability of the latter.

Since July 1, 2010, Federal Law of December 22, 2008 N 262-Ф3 “On ensuring access to information on the activities of courts in the Russian Federation" came into force, which provides for the provision of information on the activities of courts, including in the form of an electronic document [3]. However, part 2 of article 5 of this Federal Law states that "Access to information on the activities of courts is limited if the information is referred in the manner established by federal law to information constituting state or other secrets protected by law". Other secrets include, among others, the attitude of a particular person to religion and the mystery of confession. Part 5 of Article 15 of this Federal Law defines the range of judicial acts not to be posted on the Internet. These include the texts of judicial acts issued in cases concerning, inter alia, state security, sexual integrity, the citizen's legal capacity - crimes that followers of Satanism are often accused of.

Next, we list judicial acts against satanic groups in the public domain. The first group includes judicial acts in the text of which two or more persons are mentioned who share a satanic worldview:

1. Case No. 58-007-95, two persons committed murder with particular cruelty, on the basis of satanic teachings, FULL NAME1 is convicted under Art. 105 p. 2 p.p. "д, ж" of the Criminal Code $\mathrm{R}$ of the Russian 
Federation (Criminal Code), FULL NAME2 - p. “д, ж” part 2 of article 105 of the Criminal Code of the Russian Federation and p.p. 5 Article. 33 of the Criminal Code of the Russian Federation [4].

2. Case No. 3-11 / 2010, the religious group "The Noble Order of the Devil" is recognized as an extremist organization, its activities are prohibited. FULL NAME1 was found guilty of committing crimes under Part 1 of Art. 239 and Art. 135 of the Criminal Code of the Russian Federation, FULL NAME2 under Part 2 of Art. 239 of the Criminal Code of the Russian Federation [5].

3. Case No. 1-168 / 2011, according to the sentence, FULL NAME1 testified that he was a member of the informal group of "Satanists". FULL NAME1 was found guilty of crimes (abuse of the burial places of the deceased), provided for by paragraph "a" of Part 2 of Art. 244 of the Criminal Code of the Russian Federation and paragraph "c" of Part 2 of Art. 158 of the Criminal Code of the Russian Federation [6].

4. Case No. 33-1667, refers to a group of 7 Satanists who were convicted by a verdict of the Tula Regional Court on February 11, 1999 for committing a ritual murder [7].

5. Case No. 22-1740/2014 refers to a person in a satanic group who is found guilty of an offense (murder) under Part 1 of Art. 105 of the Criminal Code of the Russian Federation [8].

6. Case No. 22-5855/2018, a person made a human sacrifice to Satan, convicted under part 5 of Article 33, p. "A", part 2, Article 105 of the Criminal Code of the Russian Federation [9].

It should be noted that there are a number of crimes universally recognized by members of satanic religious groups, but not mentioned here because of the lack of open access to texts of judicial acts on these crimes. These include, at a minimum, the killing of Karina Buduchyan [10] and the ritual murder in Yaroslavl of 2008.

The second group includes judicial acts, the text of which contains information about individuals who share a satanic worldview or who associate themselves with a minister of Satan.

1 Case No. 22-210/2012, a person convicted of murder under Part 1 of Art. 105 of the Criminal Code of the Russian Federation, claimed that at the 
time of the murder he obeyed the Devil [11].

2. Case No. 22-406 / 2014, a person convicted of murder was convicted under Part 1 of Art. 105 of the Criminal Code, the material mentions a note in which a person requests a meeting with Satan [12].

3. Case No. 1-31/2014, a person convicted of fraud, part 2 of article 159 of the Criminal Code, during rituals at the cemetery stated that he acts with the support of Satan [13].

4. Case No. 1-142/2016, a person who participated in a household brawl, previously talked about the Devil [14].

5. Case No. 2-2566/2016, a person convicted of murder under Part 1 of Art. 105 and p. 1 Article 167 of the Criminal Code, the case materials mention that he called himself a Satanist [15].

We should note that the participants in the above judicial acts, due to ideological or other reasons, related themselves to Satanism or service to Satan. In most judicial acts, which text mentions Satan (under different names) and Satanism, the worldview of the satanic attitude of the participants in the trial is difficult to identify but it can also reflect the spread of satanic ideas through the media (thematic films, series, music, communities). Such judicial acts include those in which the court revealed a psychological disorder in individuals.

1. Case No. 1-361/2011, a person suffered from paranoid schizophrenia [16]

2. Case No. 2-3344/2011, the person suffered from paranoid schizophrenia, and called himself the Devil [17]

3. Case No. 2-2566/2016, a person suffered from paranoid schizophrenia, and called himself the Satan [18].

The presence of such persons with similar views can be both a reflection of traditional Christian views with established demonology, and the influence of modern mass media content in which the image of Satan or Satanic communities is romanticized.

\section{$4 \quad$ Summary}

The activity of satanic groups and satanic ideology is a certain challenge for the Russian Federation. On the one hand, there are constant attempts 
by Satanic groups or organizations to legalize themselves in the legal field, on the other hand, a number of criminal cases related to the activities of such groups and the radical ideology within these groups exclude this possibility. Lack of understanding of the involvement of the population in satanic groups makes it difficult to develop the correct methods of responding to new challenges. In this connection, A.V. Savvin's remark on that "the lack of objective information about the number and activities of Satanists, the real danger of occult ritual practices for the life and health of citizens leads to the escalation of tension in society" remains relevant (Savvin, 1999).

\section{$5 \quad$ Conclusions}

The presented study clearly shows that satanic ideas and a satanic worldview in the Russian Federation are broadcast to a fairly wide audience. Some thematic groups comprise more than 23,000 users who have indicated their citizenship in the Russian Federation. The activities of such communities can contribute to the selforganization of satanic groups in different cities and the transformation of their activities from virtual to real. The presented criminal cases show the development lines of such groups and their destructive potential.

Our analysis of groups in a social network shows that Satanism is predominantly urbanized, this phenomenon is confirmed by the defendants in criminal cases. It should be noted that representatives of "youth Satanism" most often become actors of judicial practice in the Russian Federation.

It should be noted that the popularity of satanic ideas in modern Russian society is caused not only by actively thematic communities in social networks. The popularity of these ideas is influenced by media content in which Satan is viewed from an alternative point of view and thus the romanticization of his image can be formed (Partridge, 2004). In modern films, series, computer games, the image of Lucifer is presented as an unjustly punished and expelled angel (or son of God), which by all available means protects humanity from creatures really wanting to destroy this humanity. Critical media content about the activities of satanic groups can also form a certain appeal among adolescents 
as a form of protest against the existing way of life, culture and state system.

\section{6}

\section{Acknowledgments}

The work is performed according to the Russian Government Program of Competitive Growth of Kazan Federal University.

\section{References}

Nosachev P.G. The splendor and misery of the "sociology of the occult": the theory of occultism by K. Partridge // Bulletin of PSTGU / Series 1: Theology. Philosophy. Religious studies. Vol. 70. 2017, - P. 110-126.

Martinovich V.A. Sectarianism: emergence and migration / Preface. L.I. Grigorieva. - M.: Publishing House 'Poznanie', 2018. - 552 p.

Federal Law N 262-Ф3 “On ensuring access to information on the activities of courts in the Russian Federation" dated December 22, 2008 [Electronic resource] / Reference and Legal System "Consultant Plus". - URL: http://www.consultant.ru/cons/cgi/onlin e.cgi?req=doc $\&$ base $=L A W \& n=286518$ $\&$ fld $=134 \&$ dst $=1000000001,0 \& \mathrm{rnd}=0.6$
754221675162932\#0438184027578404

8 (accessed date: 13.02.2019).

The decision of the Supreme Court of the Russian Federation of February 14, 2008 on case No. 58-007-95 [Electronic resource] / Internet resource "SudAkt". URL:

http://sudact.ru/vsrf/doc/24iFSLCYNBx

C/ (accessed date: 13/2/2019

The decision of the Supreme Court of the Republic of Mordovia dated October 19, 2010 on the case No. 3-11/2010 [Electronic resource] / Reference and legal system "Pravo.ru". - URL: http://docs.pravo.ru/document/view/169 69568/ (accessed date: 13.02.2019).

Sentence of the Primorsky District Court of the city of Novorossiysk dated June 16, 2011 on the case No. 1-168/2011 [Electronic resource] / Internet resource "SudAkt". URL: http://sudact.ru/regular/doc/dVyKNYw KFhn/ (accessed date: 13.02.2019).

Decision of the Tula Regional Court dated June 21, 2012 on the case No. 331667 [Electronic resource] / Internet resource "SudAkt". - URL: 
http://sudact.ru/regular/doc/YgZfZyqX

DTJr/ (accessed date: 13.02.2019).

The appellate judgement of the Moscow Regional Court dated May 13, 2014 on the case No. 22-1740/2014 [Electronic resource] / Internet resource "SudAkt". URL:

http://sudact.ru/regular/doc/wg9RIDlnV MQB/ (accessed date: 13.02.2019).

The appellate judgement of the Sverdlovsk Regional Court dated August 16, 2018 on the case No. 22-5855/2018 [Electronic resource] / Internet resource "Judicial decisions of the Russian Federation". - URL: http: //xn-90afdbaav0bd1afy6eub5d.xn-p1ai/35707676 (accessed date: 13.02.2019).

The appellate judgement of the Saint Petersburg Regional Court dated March 5, 2015 on the case No. 33-2256/2015 [Electronic resource] / Internet resource "SudAkt". URL: http://sudact.ru/regular/doc/S942troj3g $\mathrm{Wu}$ / (accessed date: 13.02.2019).

The cassation judgement of the Tyumen Regional Court dated February 2, 2012 on the case No. 22-210/2012 [Electronic resource] / Internet resource "SudAkt". URL:

http://sudact.ru/regular/doc/c5PFMrRhb rrO/ (accessed date: 13.02.2019).

The appellate judgement of the Supreme Court of the Republic of Tuva dated March 25, 2014 on the case No. 22406/2014 [Electronic resource] / Internet resource "SudAkt". - URL: http://sudact.ru/regular/doc/1ODVzkwc bx1J/ (accessed date: 13.02.2019).

Sentence of the Ziminsky city court of the Irkutsk region dated April 2, 2014 on the case No. 1-31/2014 [Electronic resource] / Internet resource "SudAkt". URL:

http://sudact.ru/regular/doc/sYT6eit62o Y6/ (accessed date: 13.02.2019).

Sentence of the Sverdlovsk District Court of Irkutsk of March 14, 2016 on the case No. 1-142/2016 [Electronic resource] / Internet resource "SudAkt". URL: http://sudact.ru/regular/doc/4rpqwfX56 $\mathrm{gmm} /$ (accessed date: 13.02.2019). 
Decision of the Zheleznodorozhny

District Court of Voronezh of March 9, 2017 on the case No. 2-2566/2016

[Electronic resource] / Internet resource "SudAkt".

URL: http://sudact.ru/regular/doc/HCD2Obg7 Imdx/ (accessed date: 13.02.2019).

Regulation of the Izmailovsky District Court of the city of Moscow of August 25, 2011 on the case No. 1-361/2011 [Electronic resource] / Sudakt Internet resource. URL: http://sudact.ru/regular/doc/j6zYHMs3f XL9/ (accessed date: 13.02.2019).

Decision of the Ostankino District Court of Moscow dated March 21, 2012 on the case No. 2-3344/2011 [Electronic resource] / Internet resource "SudAkt". URL:

http://sudact.ru/regular/doc/o4Fr2YOGd $\mathrm{ZdO} /$ (accessed date: 13.02.2019).

The judgement of the Prokhladnensky District Court of October 2, 2015 on the case No. 1-241/2015 [Electronic resource] / SudAKt Internet resource. URL: http://sudact.ru/regular/doc/2TgfDjPgM $\mathrm{DgW} /$ (accessed date: 13.02.2019).
Savvin A.V. Modern Satanism [Electronic resource] / Man and science. 1999.

URL: http://cheloveknauka.com/sovremennyy -satanizm (accessed date: 13.02.2019).

Partridge C. The Re-Enchantment of the West Vol. 1: Alternative Spiritualities, Sacralization, Popular Culture, and Occulture, 2005. 255 p 